\title{
ARTISTICALLY TALENTED STUDENTS: A CALL FOR RESEARCH
}

\section{Dale Boland}

\section{Problem}

The identification and development of art talent have long been recognized as goals of art education. Model programs have been designed and implemented to provide differential curricula tailored to the needs and abilities of students talented in the visual arts. However, although art teachers and teachers of the gifted/talented may be highly trained and accomplished in their content areas, they may not be prepared to cope with problems and behaviors which result from the nature of artistically talented learners.

Hurwitz (1983) states that the number of programs for students gifted/ talented in the visual arts has been increasing nationwide in the past decade, especially at the senior high level. It would appear that art educators are embarking on a new era of understanding and of revitalized interest in the artistically talented based on decades of modern research.

However, as Clark and Zimmerman (1984) pointed out, although great strides have been made in the field of gifted/talented education, there is an apparent need for research to resolve inconsistencies and contradictions that emerge from past inquiry about artistically talented students. Artistically talented students, as a unique research population, have not been studied with the depth of inquiry that exists about students who are intellectually gifted. Therefore, many questions remain unanswered and many problems unsolved (p. 61).

One area of contradiction pertinent to this investigation, for example, is research concerning the relationship between IQ and artistic talent. Lowenfeld and Brittain (1964) have claimed that the results of intelligence tests cannot be used as indicators of artistic talent, whereas many researchers, from 1919 to the present, have claimed that an above-average 
IQ is prerequisite to the production of meritorious art (Ziegfeld, 1971; Vernon, Adamson, and Vernon, 1977). Other researchers conclude that above-average IQ is a necessary condition but not sufficient to guarantee art talent or creativity (Hollingworth, 1923; Birch and McWilliams, 1955; Schubert, 1973). Clark and Zimmerman (1984) present a conception of artistic talent in which parallels are drawn between the representation of intelligence on a normal distribution and the representation of talent in art on a naive-to-sophisticated continuum in which evidence of art talent declines as intelligence diminishes. This relatively new viewpoint holds many possibilities for future research.

\section{Purpose}

The four purposes of this paper are: (a) to define "artistically talented" learners; (b) to explore the nature of these students by listing the characteristics of the art products and the observable behaviors of students with superior abilities in the visual arts; (c) to identify curriculum considerations for the artistically talented; and (d) to call for research especially in the areas of counseling and guidance as a means of helping teachers meet the educational, social, and psychological needs of the artistically talented.

\section{Definition of Artistically Talented}

In the literature, the terms "gifted," "talented," and "gifted/talented" are sometimes used interchangeably to describe a vaguely-defined population. To add to the confusion, "intellectually gifted" is used to describe those students who score at least two standard deviations above the mean on standardized intelligence tests and score at least two grade levels above their age peers on achievement tests, especially in the areas of math and reading (approximately three to five percent of the population). The abilities of the intellectually gifted are sometimes referred to as "talents." Similarly, talents in the visual or performing arts are sometimes referred to as "gifts." 
Chapman (1978) says that around the turn of the century, "artists were often viewed in terms of two stereotypes: the inspired genius or the suffering hero" (p. 8). Formerly, gifts and talents were considered by some to be God-given, a devine trust (Witty, 1951), unquestionably inherent. This viewpoint has been modified to explain the frequent disappearance of early talent and the facility with which talent can be developed in almost any area when the learner receives intensive training and works consistently to improve performance.

The term "talent" is most commonly applied to exceptional performance in such areas as atheletics, drama, dance, mechanical skill, leadership, music, and the visual arts. The literature indicates that a talented child or youth stands out from his age-mates in some special capacity, demonstrating outstanding performance (Bloom, 1982), with a high degree of sensitivity and dedication. Bloom (1982) emphasizes the importance of key teachers whom talented youth credit with helping them develop their potentials.

Taylor (1976), attempts to identify factors common to different types of outstanding performance: (a) academic ability; (b) creative ability; (c) planning; (d) communication; (e) forecasting; and ( $f$ ) decision-making.

Laycock (1957), draws a distinction between "gifted" and "talented." He applies the first of these terms to people who have been determined to have a high degree of general intellectual capacity, the latter to specific achievements that are largely the result of special training.

The federal government's definition (Maryland, 1972) states that gifted/ talented learners are:

Children and youth who are identified at the preschool, elementary, or secondary level as possessing demonstrated or potential abilities that give evidence of high performance areas such as intellectual, creative, specific academic, or leadership ability, or in the performing or visual arts, and who by reason thereof, require services or activities not ordinarily provided by the schools (p. 14). More globally, Renzulli (1977) defines giftedness as the common element in three overlapping circles which include: (a) above-average ability; 
(b) task commitment leading to product development; and (c) creativity.

Passow (1981) indicates that no single definition is suitable for all programs since gifted/talented individuals encompass a wide range of traits and behaviors. Therefore, programs for artistically talented students should be based on specific goals developed for that population, for "the conception of the nature of giftedness and talent is at the heart of the planning effort" (p. 43).

As many experienced art teachers have observed, not all intellectually gifted students develop a talent in art or even excel academically, and not all artistically talented students are exceptionally intelligent. Also, a student may be talented in art criticism without being highly accomplished in studio art production, and vice versa.

What is a suitable definition for students talented in the visual arts? In this paper, the term "artistically talented" refers to individuals, especially school-aged students, who show an exceptionally high ability in one or more areas of the visual arts, such as drawing, painting, sculpture, ceramics, printmaking, photography, textiles, or art criticism. These students demonstrate outstanding performance in the visual arts with a high degree of sensitivity and dedication.

\section{Characteristics of Artistically Talented Learners and Their Art Products}

Many studies of the characteristics of the gifted/talented have resulted in various lists of behaviors and traits indicative of such individuals. Most

of these lists are indebted to the classic studies of Cox (1926) and Terman (1959), including their longitudinal studies.

Artistically talented students have a high readiness level for learning about art. Since their IQ is at least above-average, they are able to learn at a faster rate and exercise higher levels of abstract thought (Gallahger, 1975). Their task commitment, almost bordering on obsession, leads to rapid mastery of techniques and a unique sensitivity to media (Hurwitz, 1984). These factors, in combination with their creative abilities and a 
favorable environment, allow the individual to produce works of art which are significantly different from their age-mates, often surpassing the quality of the artwork their teachers and mentors produce (Clark and Zimmerman, 1984).

The artistically talented, according to Hurwitz (1984): (a) show evidence of talent; (b) depend on drawing as a primary means of expression; (c) progress rapidly through the stages of artistic development; (d) demonstrate extended concentration; (e) are self-directed and independent; ( $f$ ) are often reluctant to take risks; ( $g$ ) use art as escape; (h) show fluency of ideas and expression; and (i) have a superior ability to utilize past information in new contexts. Characteristics of their artwork include: (a) verisimiltude (realistic, literal portrayal in a descriptive drawing); (b) compositional control; (c) complexity and elaboration of schemas; (d) evidence of a good memory; (e) attention to detail; ( $f$ ) sensitivity to art media; and (g) random improvisation.

Clark and Zimmerman (1984) have compiled the results of many studies and made an outline of the characteristics of the art products and observable behaviors of students with superior abilities in the visual arts. Listed below are the highlights of their investigation.

The researchers found that the art products of artistically talented students are: (a) skillfully composed; (b) complete and coherent; (c) asymmetrically balanced; (d) complex, elaborate, and greatly detailed. In terms of the elements and principles of art, the colors are: (a) well-organized; (b) values are contrasted, and values and hues are subtly blended; (c) line is skillfully controlled; (d) light and shadow are accurately depicted; (e) shapes are used intentionally; and ( $f$ ) form, grouping, and movement are very strong. Some studies show that these students specialize in one subject matter while others indicate that they draw a wide variety of things. These students: (a) copy to acquire technique; (b) are adept at depiction of movement; and (c) use personal experiences and feelings as subject matter.

In terms of art-making skills, the artistically talented demonstrate: (a) true-to-appearance representation; (b) accurate perspective; (c) good 
proportion; (d) schematic and expressive representation; (e) effective use of media; ( $f$ ) obvious talent and artistic expression even though they may lack technical skills. Their art-making techniques show maximum use of tools and media. Areas of their art products are treated to display: (a) boldness; (b) blending; (c) gradation; and (d) textures. They also tend to use smaller paper. Visual narratives are used by these students for self-expression and to relate a story.

The outline compiled by Clark and Zimmerman (1984) also includes observable behaviors of students with superior abilities in the visual arts. Generalized predispositional behaviors include: (a) superior manual skill and good muscular control; (b) independence of ideas and ability to experience events from multiple points of view; (c) adherence to rules, regulations, and routine study; (d) relative freedom from ordinary frustration; (e) highly individualized differences in psychological characteristics; (f) superior energy level and rapid turnover of thoughts; (g) desire to work alone; (h) compulsion to organize to satisfy desire for precision and clarity; (i) highly adaptive in thought and activity; (j) high potential for leadership due to fluency of ideas offered in a group; $(k)$ good concentration and flexibility in adaptation of knowledge; ( 1 ) maturity for age; $(\mathrm{m})$ show better achievement in science, social studies, and language arts than in math.

Art-specific predispositional behaviors of the artistically talented, according to Clark and Zimmerman (1984), include: (a) dynamic and intuitive quality of imagination; (b) unusual penchant for visual imagery and fantasy; (c) intense deire to make art by filling extra time with art activities; (d) high desire for visual awareness experiences; (e) high desire in drawing representationally or to emulate the style of adult artists; (f) self-initiative to make art work; (g) finds satisfaction in doing art activities with a high degree of sustained interest; $(h)$ desire to improve own art work; ( $i)$ perseverance and enthusiasm; ( $j$ ) willingness to explore new materials, tools, and techniques; (k) ambitions for an art career; (I) accurate power of visualization; $(\mathrm{m})$ require high degree of motivation; (n) may manifest early or late talent, but talent may not persist to maturity; (o) may have motor skills specific to talent, but may not have 
general motor superiority; (p) easy visual recall; ( $q$ ) extraordinary visual perception skills; $(r)$ planning art production before production; and (s) superior handwriting is not necessarily correlated with artistic talent. In terms of observable process behaviors, the artistically talented demonstrate: (a) originality and idiosyncratic depictions; (b) completion of product; (c) subtle or more varied graphic vocabulary; (d) fluency and experimentive use of picture vocabulary; (e) flexibility; ( $f$ ) confidence and comfort with art media and tasks; ( $g$ ) purposefulness and directness of expression with clarity; $(h)$ clear understanding of structure and a sense of the inter-relationships of parts in an art work; $(i)$ skill in giving objective reasons for critical judgment in artwork of others; (j) genuine interest in the artwork of others; and (k) application of critical insights to own artwork.

\section{Curriculum for Artistically Talented}

The curriculum in a program for artistically gifted/talented students should be defined as accelerated and enriched learning experiences about art history, art criticism, art production, and aesthetics. Settings for special programs may be in schools, musems, community agencies, or other places supportive of the goals and philosophy of the program.

Szekely (1981) has shown that teachers with experience in working with gifted/talented students and who have expertise in an art form are able to help the artistically gifted/talented to maximize their potential. These students can be led to very sophisticated forms of expression based on the role models of the artist, art critic, art historian, or aesthetician.

Passow (1960) and Ward (1961) identify and justify the general principles of a differentiated curriculum for gifted/talented students as an area of special education. The broad goals listed below could be adapted to a differentiated curriculum for artistically gifted/talented. These researchers say that curriculum planners for artistically gifted/talented programs should: (a) present content that is related to broad-based themes, issues, or problems; (b) integrate multiple discipline into the area of study; 
(c) allow for the in-depth learning of self-selected topics within the area of study; (d) develop independent or self-directed study skills; (e) develop complex, productive, abstract, and/or higher level thinking skills;

( $f$ ) focus on open-ended tasks; ( $g$ ) develop research skills and methods;

(h) integrate basic skills and higher level thinking skills into the curriculum; ( $i$ ) encourage the development of products that challenge existing ideas and produce "new" ideas; $(j)$ encourage the development of products that use new techniques, materials, and forms; (k) encourage the development of self-understanding, i.e. recognize and use one's abilities, become self-directed, and appreciate likenesses and differences between oneself and others; and ( 1 ) evaluate student outcomes, using appropriate and specific criteria through self-appraisal, criterion-reference and/or standardized instruments (pp. 43-45).

In short, a curriculum for the artistically gifted/talented should be more demanding and challenging, it should be accelerated in pace and amount of material to be learned, and it should establish higher levels of achievement that demand the greatest degree of independent activities and learning possible. Learning experiences for these young artists should extend beyond the walls of the classroom into the community and regional resources. By bringing together these students with others like themselves, they are challenged by peers of similar ability, often critiquing and learning from each other.

\section{A Call for Research}

Although there have been many fine studies about the artistically talented as a unique population, they deserve to be better represented in the literature of art education. These students offer a rich source of subject matter for graduate research. There is a need for identification procedures, reliable instruments, correlation studies, longitudinal studies, ideas for differential curricula, and innovative programs. The areas of art criticism and aethetics for gifted/talented learners and art curriculum for the intellectually gifted are virtually unexplored. More attention 
needs to be given to talented students who are not served in gifted programs because they do not score high enough on standardized tests. The quantification of art behaviors, a difficulty in some past studies, needs to be addressed by researchers who have a background in art education. Futuristic studies present a challenge for researchers who want to predict how computers, robotics, and other technological advances will affect the artistically talented in the future.

Art teachers, many of whom were themselves artistically talented youth, need to become better informed about the characteristics of the artistically talented and their products, and they need to become aware of alternate methods of responding to these students during art instruction. The field of counseling and guidance offers the following therapeutic approaches to dealing with unique populations: (a) Client-centered therapy; (b) Rational-emotive therapy; (c) Psychoanalysis; (d) Gestalt therapy; (e) Adlerian psychotherapy; and ( $f$ ) Behavior counseling. Rsearchers could find out if these strategies, which have been successful in other settings, can be applied to art instruction in the classroom.

\section{REFERENCES}

Birch, J. and McWilliams, E. (1955). Challenging gifted children. Bloomington, IL: Public School Publishing.

Bloom, B. (1982). The master teachers. Phi Delta Kappan, 63, 664-668.

Chapman, L. (1978). Approaches to art in education. New York:

Harcourt, Brace, Jovanovich, Inc.

Clark, G., and Zimmerman, E. (1984). Educating artistically talented students, California: Syracuse University Press.

Cox, C. (1926). The early mental traits of three hundred geniuses.

Genetic Studies of Genius. Stanford, California: University Press. Gallagher, J. (1975). Teaching the gifted child. Boston: Allyn and Bacon. Hollingworth, L. (1923). Gifted children: their nature and nurture. New York: Macmillan.

Hurwitz, A. (1983). The gifted and talented in art - A guide to program 
planning. Worcester, Massachusetts: Davis Publications, Inc.

Laycock, S. (1957). Gifted children: a handbook for the classroom teacher.

Toronto, Canada: Copp-Clark.

Marland, S. (1972). Education of gifted and talented: report to the

Congress of the United States by the U.S. Commissioner of Education.

U.S. Department of Health, Education, and Welfare, Office of Educa-

tion, Washington, D.C.: Government Printing Office.

Passow, A. (1960). The gifted and talented: their education and develop-

ment. New York: Teachers College, Columbia University.

Passow, A. (1981). The nature of giftedness and talent, Gifted Child

Quarterly, 25 (1).

Lowenfeld, V., and Brittain, W. (1964). Creative and mental growth.

New York: Macmillan.

Renzulli, J. (1978). What makes giftedness: re-examining a definition,

Phi Delta Kappan, 60 (3), 180-184.

Schubert, D. (1973). Intelligence as necessary but not sufficient for

creativity. Journal of Genetic Psychology.

Szekely, G. (1981). The artist and the child - a model program for the

artistically gifted. Gifted Child Quarterly, 25 (2), 67-72.

Taylor, C. (1976). Using biographical information to identify artistic

talent. Gifted Child Quarterly, 20 (4), 402-413.

Terman, L., and Oden, M. (1959). Genetic studies of genius. Stanford,

University Press.

Vernon, P., Adamson, G., \& Vernon, D. (1972). The psychology and educa-

tion of gifted children. Boulder, CO: Viewpoint Press, 1977.

Ward, V. (1961). Educating the gifted: an axiomatic approach. Columbus,

Ohio: Charles E. Mlerrill.

Witty, P. (1951). The gifted child. Boston: D.C. Health.

Ziegfeld, E. (1971). Art for the academically talented student in the

secondary school. Washington, D.C.: NAEA/NAEA.

Working Papers in Art Education 1986 